\title{
EXPLORING THE HINDU/MUSLIM DIVIDE THROUGH THE PARTITION OF BENGAL*
}

\author{
Maurice O'Connor \\ Universidad de Cádiz
}

\section{Abstract}

In this paper we shall explore the move from localised to politicised identities in Bengali society and evidence how religious affiliation became a central consideration within this shift. The growth of communalism, we shall argue, has much to do with the colonial strategy of establishing separate electoral systems for Hindus and Muslims, cementing the separation between these religious groupings. Our critical interest centres around the Partition of Bengal, and we shall employ memoirs and literary texts, written in Bengali and translated into English, so as to elucidate upon the complexities of the Hindu/Muslim relationship. We shall argue that the unresolved issues of Partition still cast their shadow on contemporary India, and shall draw connections between past and present manipulations of religious identities for expedient political ends.

Keywords: Communalism, Hindu/Muslim divide, Historicity, Partition, Religious identities.

\section{RESUMEN}

En este artículo estudiaremos el cambio de identidad local a identidad nacional en la sociedad bengalí y cómo la religión tuvo un papel central en el mismo. El auge del sectarismo religioso estuvo relacionado con la estrategia de las autoridades coloniales de crear colegios electorales distintos para musulmanes e hindúes, lo que claramente abrió una brecha insalvable entre ambas comunidades. Para conocer mejor la complejidad de las relaciones sociorreligiosas, nos centraremos en los efectos de la Partición en Bengala y al efecto recurriremos a memorias y textos literarios escritos en bengalí y traducidos a inglés. Inferimos que la Partición dejó irresoluta una serie de problemas que afectan a India en la actualidad, debido a la manipulación de la identidad religiosa con fines políticos, en el pasado tanto como en el presente. Palabras Clave: enfrentamiento, hindúes-musulmanes, historicidad, identidad religiosa, partición, sectarismo religioso. 
The measure of which religious belief plays a central part in defining Indian political realities needs to be contextualised within a specific historical context. Certainly, as Gyanendra Pandey assures, Partition brought about an intensification of religious affiliation as an identity marker and resulted in, "zamindars stopped being zamindars and started being Hindus and Muslims" (50). For the majority of Muslims, Hindus and Sikhs, survival came before the defending of any specific religious identity. On the contrary, as Alok Bhalla assures, the peasant's affiliation with their zameem, a term that refers to a "piece of land" in Hindi, Urdu, Telugu, Tamil and Malayalam alike, indicates that an intimate connection with the local held more importance in contrast with the abstractions of religious identity (4). One, therefore, cannot understand contemporary India, its divisions and conflicts, without a profound engagement with Partition and the question of religious identities. Considering that the partition of West Pakistan has received greater critical attention, it is our aim to examine the partition of Bengal through the lens of the religious affiliation as a means to enhance an understanding on current communal conflicts in India. In this light, we shall question the veracity of the so-called Hindu/ Muslim divide by providing a more layered reading of religious identity in both East and West Bengal, firstly through a historiographic perspective, and secondly through an analysis of post-Partition Bengali literature, translated into English.

\section{THE INSTRUMENTALISING OF RELIGIOUS IDENTITIES IN BENGAL}

First of all, one must differentiate between Bengali Muslim identity and the Muslim identity of the western provinces of India. In the latter, many Muslims can claim Persian ancestry, whilst in the former, as Sumit Sarkar (1973) evidences, many Bengali Muslims were of low-caste Hindu origin, Buddhists or simply people who had never been fully assimilated into the structure of Aryan society and thus were attracted to Islam's message of egalitarianism (346). Despite having converted to Islam, these new Muslims displayed large degrees of syncretism, a perception Sarkar verifies through his reading of the 1909 Imperial Gazetter which evidences how lower-class Muslims joined in the Durga Puja and other Hindu festivals, while Muslims also consulted Hindu almanacs and worshiped Sitala and Manasa. This syncretism worked both ways as Hindu peasants (and sometimes even zamindars) offered their respects to Muslim pirs. Historical evidence of syncretist cults such as Satyapir also exists where the Sufi tradition supplied an intellectual sanction to these "eclectic admixtures" (Sarkar 347).

* This essay was funded by the Ministry of Economy and Competitiveness, Spain. Project FFI2015-63739-P: "The Aesthetics of Remembering: Empathy, Identification, Mourning" 
The aforementioned thus evidences how one cannot view the category of Hindu and Muslim as being incommensurable and, as Rakesh Batabyal (2005) indicates, communalism was moreover "a product of the modern age, which unleashed these historical forces in the colonized countries" (21). To gain a deeper understanding into the birth of communalism and its supplementary discourse, the perceived "Hindu/Muslim divide", one must look at Lord Curzon's 1905 division of Bengal, a division aimed at weakening the Indian nationalist movement. This lasted until 1911 when Bengal was reunified due to a united front against it; proof that a common Bengali identity had prevailed over communalism. Therefore, interpreting communalism as something essential within the Indian "character" denies, "the existence of a colonial context, and of the historical experience of a substantial section of humanity as colonial subjects" (Batabyal 24). When the colonial state negotiated between different communities so as to safeguard its own interests, what it was effectively doing was to give new political meaning to the concept of what it meant to be Hindu or Muslim and this, ultimately, created new antagonisms that previously did not exist. Therefore, one must look deeper into the affirmation that conflicting religious identities were the root cause of Partition and that violence was a natural expression of these incommensurable positions. While we cannot deny that socio-cultural differences did exist and that certain antagonisms came about as a result of these differences, these came into sharp focus at the beginning of the twentieth century.

Sarkar assures that the administrative arguments in favour of this partition were a "deep imperialist design of 'divide and rule", and this is a view that is endorsed by the majority of Indian scholars writing on the subject (11). In his speech in Dacca (18 February, 1904) Curzon assured that this partition would, "invest the Mohammedans in Eastern Bengal with a unity which they have not enjoyed since the days of the old Mussulman Viceroys and kings" (quoted in Sarkar 1973: 16), and for this reason a large section of the Muslim gentry supported partition due to the devolved powers it afforded them. Although the Swadeshi movement (19031908) was a heterogeneous movement that encompassed "a common culture at the village level based upon an amalgam of Hindu, Buddhist, Muslim and primitive folk elements", it was, moreover, the initiative of a Hindu elite that saw partition as a clear affront to its hegemony (Sarkar 1973: 19). So, although many Muslims were involved in the movement, the Muslim intelligentsia felt more comfortable with securing its own hegemony in East Bengal.

The second and final Partition of Bengal came about precisely because of a breakdown of mutual trust between Hindus and Muslims. Bidyut Chakrabarty (2004) assures that, "Capitalising on the disproportionate development between the two communities, the Muslim political forces strengthened their claims for a separate state", and the Hindu elite, seeing that its own influence was becoming eroded, gave no real opposition to this idea (36). In Bengal, nine-tenths of zamindaris were held by Hindus, while the landless peasants were mostly Muslims. Furthermore, the bhadralok (Hindu elite in Bengal) had performed a more successful assimilation to the colonial culture when compared to their Muslim counterparts who fell behind in education and had lost political leverage as a result. The rise of communalism 
can thus be viewed as a Muslim middle-class struggle that was provoked by the imbalances created within a colonial/capitalistic system. Having lost faith in colonial politics due to the aforementioned lack of assimilation, Muslims turned to communalism as a means of garnering power (Batabyal 24).

Therefore, the idea of communalism, as we know it, was a modern phenomenon, something separate from the older discourses of mere cultural difference and, as Prabha Dixit assures, it was, moreover, a political doctrine (3). The modernisation of the Muslim community as heralded by Syed Ahmed, a Bengali nineteenth-century Islamic reformer, was only focused on upper-class Muslims and, in this context, communalism was a convenient tool to gain power (Dixit 56). The conclusion Dixit reaches is that this doctrine of creating a Muslim identity for political ends provoked the birth of Hindu communalism as a reaction to Muslim communalism. The tragic outcome of this was that a strategic positioning through communalism gave way to old grievances becoming magnified within this new political scenario.

The eventual Partition of Bengal was in the making long before its overt political expression. The 1932 Communal Award was the outcome of the 1909 Morley-Minto Administration Reformation Act that established separate versus joint elections, and this cemented the separation of Hindus and Muslims through the splitting of the Indian electorate primarily upon religious/ethnic grounds. This was, no doubt, an instrumentalisation of communalism through the establishing of rival modes of election and, as Chakrabarty (2004) assures, the 1909 Morley-Minto reform "stamped the two-nation theory on the political fate of the country" (152). We must also remark upon the failure on behalf of the Indian National Congress to integrate Muslims into the nationalist movement, and it is notable that at the 1932 Unity Conference, convened at Allahabad so as to discuss the nefarious effects of the Award, no Muslim leaders attended as they saw separate electorates as being the only means for Bengali Muslims to truly come into power. A common Bengali identity was now replaced by a communal identity, and the aforementioned colonial rubric of divide and rule conveniently worked in tandem with a strategic positioning by Muslim leadership to garner their own new set of privileges. This configuring of Muslims and Hindus into separate political groupings played an important role in creating an ambience of animosity.

In conjunction with the 1932 Communal Award,one, however, must also look at the changing socio-economic situation in Bengal and, specifically, at the role of the Hindu talukdars (the landowning aristocrats) who were also mahajans, money lenders and lenders of grain during lean periods. The Great Depression in the 1930s in Bengal greatly affected the demand for jute and made the peasant community much more economically vulnerable. This Great Slump also affected the Hindu aristocracy who could no longer sustain their function of mahajans. This created a socio-economic schism in that the talukdars lost social credibility within the Muslim-dominated small peasant economy of East Bengal and were now conceived as parasites (Chakrabarty 48). Muslims with different political commitments became united under a religious banner and this, in turn, gave credence to a communalistic ideology. The founding of the Krishak Praja Party (KPP) helped galvanise Muslim identity against Hindu economic dominance, and the subsequent 
KPP-Muslim League alliance after the 1937 elections changed the nature of politics in East Bengal (Chakrabarty 2004: 50). It was in the interests of political leaders to insist upon the religion of the zamindar oppressors and, for example, to underplay the exploitive role of the Muslim landlords (Chakrabarty 36). Islam, therefore, now provided the Muslim peasants a unifying ideology against the zamindars, and although their grievances derived, moreover, from issues of class privileges, these grievances took on a communal colour (Chakrabarty 2004:86). Certainly, the Bengali bhadralok traditionally had always guarded their own interests first; for example, the Indian Congress, dominated by upper-caste Hindus, vetoed the 1928 Bengal Tenancy Act which proposed to give peasants rights over a traditional zamindar privilege, and the fact that the landless peasants happened to be Muslims made it easier for them to adopt their position. In the face of new political realities, this rentier Hindu class made no real move to attend to Muslim fears class, and they became more interested in their own privileges, less interested in opposition to foreign rule. Especially in rural East Bengal, the Muslim peasantry saw Hindu party politics as a tool of oppression against them and this consolidated the idea of political Islam (Chakrabarty 2004: 41).

The Scheduled Castes also suffered from poverty and social exclusion, and this created a certain sympathy for the Muslim League as excluded Hindus and Muslims alike suffered under a Hindu zamindar elite. However, from 1937 onward, the League Ministry brought in legislative acts to protect the interests of the Muslim community, which created an in-built communal bias regarding most of the legislations adopted by the Muslim ministry in Bengal. These communal devices, overseen by Chief minister Fazlul Haq, were introduced to re-address a historical disadvantage (for example, $80 \%$ of all recruited teachers were now Muslims, the rest being divided between Hindus and Scheduled Castes), and the effect was to create what Chakraborty (2010) defines as an "unprecedented toxin of communalism" (114). Feeling that they were being side-lined by this rise in Muslim power, Bengali Hindus rallied together under the figure of Rabind ranath Tagore to protest against the diminishing of Hindu stature within Bengali politics. The 15 July, 1936 rally, in Calcutta was an indication of Hindu unrest, and this was paralleled by the Scheduled Castes who had also become disillusioned with the Bengal Provincial Muslim League. This was aggravated by the fact that, during the Calcutta and Noakhali riots, they were equally targeted as much as high-caste Hindus. The outcome of this was that what was once a heterogeneous group now cohered into a single, political identity. The Scheduled Castes, traditionally situated outside of the upper-caste Hindu sphere, now affiliated with the umbrella term "Hindu" and, especially in East Bengal, this took on a communalistic identity. Re-establishing Hindu dominance in Western Bengal was thus preferable to national unity in the eyes of the upper caste leaders of the Congress and the Hindu Mahasabha and, as Chatterji has suggested, this political manoeuvring stalled the possibility of a Dalit-Muslim alliance. 


\section{AN INTIMATE OTHER}

What emerges from this analysis is that the instrumentalisation of religious affiliation created a new configuration of identities which was, in a greater part, manipulated by a colonial apparatus for its own expedient ends. A paradigmatic shift placed communities seeing themselves vis-à-vis an "other" which was, in many cases, an uncanny extension of the self. Yet, while the established narrative has been that Hindus and Muslims could not live together and therefore Partition was the only solution, many literary texts deny this Manichean assumption. In Sunil Gangopadhyay's Arjun (1987), set in the era following the partition of East Bengal, the protagonist's father longs for a return to an older time where, "The drums and cymbals would once again deafen the ears as the devotional rituals of the arabi was carried out [...] Hindus and Muslims will embrace each other as brothers and the past will be past" (48). This sentiment is repeated by the dislocated peoples of Partition, and Chakrabarty (2010) has identified the idea of a close bond between the two religious communities. This idea of inter-communal rapport is, however, seen more as a myth, existing within a utopian ideal with no historical frame. Chakrabarty juxtaposes the recall of this idealised era, where there was harmony between Hindus and Muslims, with the eruption of violence at Partition and how this was perceived as "sudden" and thus inexplicable (148). This leads to a tendency to imagine a pure pre-Partition homeland, located on a de-contextualised plane (150).

To explore further how Hindu/Muslim relationships were perceived, we shall turn to Sunanda Sikdar's A Life Long Ago (2012), which describes the author's life as a young girl growing up in rural East Bengal in the 1950s. The narrator, a refugee in Calcutta called Daya, assures she has suppressed all memories of East Bengal: "I'd block all this out [...] It was as though my life had actually started from January 1961 " and the recuperation of these memories is, in part, an attempt to re-create the idyll of childhood (2). The singular topography of interconnecting river ways isolates the village from the political violence that Partition creates and, in part, lends to the trope of idealism present within Sikdar's memoir. This geographical isolation means that the political realities of the new nation state have not impinged upon the village and, as the narrator Daya observes, "I doubt that anyone knew that the village of Dighpait was situated in a Muslim nation. People trembled in fear of the Hindu zamindar" (40). The text, furthermore, examines the relationships between Hindus and Muslims through the trope of pollution, a fear that one will lose one's caste if strict codes are not observed. This form of social apartheid also extends to Muslims; despite the fact that Ma shows solidarity to a repudiated Muslim by employing her to pound rice; she will not allow Dibya to pound certain rice as it must, first of all, be soaked in water which means she will pollute the rice. While the Muslim woman understands and accepts this ritualised behaviour, ultimately, this hierarchical ideology mars conviviality. How this Hindu ideology creates social friction is contextualised through the intimate relationship between Daya's father and the Muslim, Sobahan. Daya's father is headmaster of a prestigious school in East Bengal and is now returning to Dighpait for the last time before moving to West Bengal. In a gesture of admiration and love, Sobahan sets about elaborate food 
preparations so as to honour his friend, despite knowing that, "the zamindar will excommunicate him and ensure that even the washermen and barbers don't work for your family" (110). Food celebrations are a central cohesive ritual in rural India, and Sobahan's insisting upon a rite he knows will never come to fruition evidences how conviviality is compromised by these codes of pollution.

This thwarting of conviviality is furthermore transmitted in a scene where Daya and her mother are passing through the neighbouring village of Beltia. Perhaps emboldened by the new political realities of East Bengal, the Muslim, Siraj da, reproaches Daya's mother on her adherence to pollution rites: "Your homes are burnt, you are leaving the country but you won't let go of your obduracy," he tells her, and then adds, "I'm saying this because I find it painful and upsetting. Have you ever invited me into your house and offered me a glass of water?" (25). While Ma attempts to explain her behaviour by arguing she is tied to the dictums of her faith, this mitigation does not alter Siraj da's attitude and, towards the end of the novel, his position has hardened: "[O]nce you folk leave for Hindustan I will not even enter a Hindu house to pee in it" (111). His reaction against the symbolic violence exerted upon the Muslim other has many parallels with the question of class oppression and, in this respect, the trope of pollution explored in the text helps shed light upon Chakrabarty's observation of how her informants see Partition violence as being "sudden" and thus unexplainable. Siraj da's animosity towards Daya and her mother is, nonetheless, tragic considering that Daya has already transgressed the codes of pollution through her intimate relationship with Majam, a family employee whom she considers as an older brother. In the face of warnings that Daya has "no ties of blood" with their Muslim servant and that there is "no point getting too close to him" she, nonetheless, assures that "Majam, my Dada, was the person I depended upon most, throughout my childhood" (3). In this respect, Sikdar sheds a different light upon received attitudes about the nature of the Hindu/Muslim relationship but, on the contrary, celebrates her unconditional bond of love for a Muslim peasant. For this reason, Siraj da's violent reproach becomes all the more poignant, and Daya assures the reader that his violent reaction, "has come back to haunt me at various points in my life" (111).

The aforementioned questions of pollution thus evidence how Hindus are also victims of their own intransigence inasmuch as their faith values impose an adherence to cultural mores that, ultimately, alienate them. It must be remarked that caste is not always a bulwark against poverty, something that Arjun shows us through the protagonist's impoverished family-Arjun's father died as a result of, "poverty, anxiety, and fear" (51). Yet, despite being set adrift and destitute, Arjun's mother clings to Hindu pollution rites and will not cook rice while waiting for the ferry to take them to West Bengal for fear of contamination by other inferior castes who have become their travelling companions.

Dibyendu Palit's "Hindu" (2006), set in Rampur, East Bengal furthers this premise on how caste imprisons consciousness through the story of a devout elderly man, Mathuranath, respected by Hindus, Muslims and the marginalised alike. On discovering the grotesque body of an unknown man, left to die at the side of the road, his initial reaction is to succour him. His altruistic action, however, receives the 
attention of his fellow villagers who, on the contrary, are more concerned that the flies that buzz around the man's open wounds might pollute them. They set about undermining Mathuranath's resolve, alleging that he is a Brahmin and, as such, should not pollute himself in this manner. In response, he assures that it is his duty to serve a fellow human being and that, otherwise, he will become a Sudra from that day onwards. Rather than awakening any empathy within his fellow villagers, they are railed by his pious attitude and, in an ironic tone, assure that "This almost equals the deeds of the great Mahatma. This news should reach the President of the country" (235-236). Upon Mathuranath's insistence, the body is moved to a house, yet, once it is suggested that the man in question is a Muslim, he is expelled under the pretext that the situation in Rampur is tense. In the face of this pressure, the Muslim is left to rot on the streets and the pious old man capitulates against his own better judgement. Here, we can find an indictment on how caste constructs a parallel moral universe that, while flying in the face of human dignity, becomes normalised within the collective consciousness. Mathuranath suffers from cognitive dissonance inasmuch as there exists a strong conflict between his own humanism and the codes of untouchability (in this case the Muslim other) which form the cornerstone of his religious identity. Pretending that the incident never happened becomes a mechanism of denial that restores his internal psychological consistency. The manner in which Mathuranath applies this self-regulatory cognitive process can be seen as a stand-in for a collective attitude as regards the unfathomable violence of Partition. Just as Mathuranath needs to deny to himself that he can no longer recognise the humanity of the Muslim other, the collective body performs a similar act of realigning its cognitions (the perceptions of the world) with the actions in the real world through a process of dissonance reduction.

Many Bengali writers have, nonetheless, consistently insisted upon how there has been an excessive focus laid upon questions of religious affiliation, whilst class issues have been underestimated within the historiography of Indian Partition. Batabyal, in this respect documents specific cases of class solidarity between Muslims and Hindus, something that Manik Bandyopadhyay's "The Ledger" (2006) bears out through the depiction of the lives of a Hindu and a Muslim factory workers who, having previously fought side by side for their worker's rights, now find themselves on opposite sides of the communal divide. The way one man dresses over the other is the only indication of their difference, while their shared struggle against capitalist oppression becomes their common bond. Whilst visiting his Hindu friend, the Muslim becomes trapped in a sudden spiralling of communal violence and, in his escape, finds himself in the European and upper-class Indian neighbourhood. On his way he is greeted by the smell of burning human flesh, yet once at the Sahebpara area he encounters an oasis of tranquillity. The following day he meets up with his Hindu friend at the factory gates. As agitators, neither are offered work and both are subsequently taken away by the police for protesting. Inside the police van, the Hindu advises the Muslim to, "Just say that neither you nor I have caste. You are poor and so am I. We belong to the poor community"(150). Achintya Kumar Sengupta's "Treaty" (2006) similarly explores how class can be a more pragmatic manner to define one's identity, over caste or religion, by exploring a similar bond between the 
slum dwellers, Johurali and Dinonath. Caught up in the spiralling violence of the 1946 Calcutta riots, these comrades suddenly adopt communal positions and set out to kill each other for reasons the story never reveals. Their fortuitous reencounter whilst in hiding from this same violence they have participated in rekindles their old friendship and shows them the absurdity of their actions.

Nabendu Ghosh's "Insignificance" (2006) echoes the question of class present in "The Ledger" by exploring how the instrumentalising of religious hatred compromises both the Hindus and Muslim underclass alike. This is contextualised through the story of Aziz, who is part of an ongoing tram-drivers' strike in Calcutta. Despite his tenacity in maintaining his class struggle, it is with resignation that he informs the reader that "They [the Muslim League] were handing over shining knives to young Muslim men, in order to safeguard their own narrow interests", whilst "The noble Indian ministers had tried to neutralize their strike by trying to instigate the average Muslim youth into communal violence" (121-122). When Aziz engages with a Hindu on the street to try and ascertain the level of communal tension, the Hindu replies, "You are the ones who have kept the matter alive, miyan" (124). Aziz shows the Hindu his strike card: "He wanted to say, Bhaisaab, we are different. [...] We are hungry workers. We are landless labourers [...]. Those that stab people and those that are stabbed by others are the same too" $(124,125)$. Aziz's fears, however, are materialised, and the irrationality of communality thwarts the forthcoming general strike through orchestrated rioting (we presume that these are the Calcutta riots of 1946): "They have become addicted to blood-like alcohol", the narrator observes and the short story's tragic ending sees Aziz stabbed to death while wearing a card that says "Striking Tram Worker" (127). In this respect, the narrative establishes a continuum between colonial practices and those of the autochthonous ruling class that, in a more direct manner, also monitor communal hatred. Here emerges a distinct understanding on religious identities; both the Hindu and Muslim Indian underclass are denied social justice in the name of religious unity, constructed through a fear of the other.

In A Life Long Ago we saw how the local peasants, defined as "soil-lickers", went half-starving under the indifferent gaze of the Hindu zamindars. Whilst the majority of these peasants were Muslims, many pertained to the lower Hindu castes and, as such, had more in common with the Muslim underclass than with the high-caste Hindus. However, on having lost power in the provincial Bengali institutions from 1930s onwards due to the communal awards, the bhadralok class began a campaign of shuddi (purification) and sangathan (mobilization) as a means to co-opt the lower castes such as Namasudras of north Bengal and Rajbangshis and Santals of East Bengal to create a pan-Hindu movement (Fraser 13). Gangopadhyay's Arjun, in this respect, gives witness to this strategy within an East Pakistani context where the zamindar Hindus "were desperately trying to establish a common identity of Hinduness with them [dalits] so that they could swell our ranks" (41). Caste consolidation and the creation of an artificial sense of Hinduness, however, never meant class equality, and Nabendu Ghosh's "The Saviour", in this light, becomes an indictment on the cynical nature of this new caste politics. Set near Bhabanipur, Western Bengal, the narrative opens up with the Dantesque scenes of chopped-off 
heads, bodily mutilations, and a catalogue of the horrors that, while observed from the safety of a middle-class neighbourhood, has reduced its privileged residents to a mesmerized state of catatonic fear (131). Sandwiched-in between this neighbourhood and the "other neighbourhood" are the doms who, whilst being ostracised from this "aristocratic neighbourhood", feel they too are Hindus and, as such, maintain an affiliation with the Shiva temple. In the face of ensuing violence, the doms are co-opted by the bhadralok community with cheap liquor and holiday sweets so as to serve as buffers against the imminent violence of the Muslims marauders. Despite the fact that they are not allowed to enter the temple because of pollution rites, (they are only allowed to touch its outer walls), the doms defend Shiva with their lives against the attacks. As mere cannon fodder, the Dalit hero, Jhogru, dies in the melee, "because people like Jhogru were always born to save the likes of $\mathrm{Mr}$ Bose [the stand-in for class hegemony]" (143). "The Saviour" thus becomes an allegory on the indifference of the bhadralok class for the dom underclass and serves to dramatize the hypocrisy of this elite that hijacks faith identity for expedient ends.

\section{CONCLUSION}

The division of Bengal had a trans-regional impact within India and, as Sengupta assures, the violence that erupted between the Bodos and the Muslims (2012) in Assam or the Muzaffarnagar riots of 2013 in Uttar Pradesh are clear examples of this. Chakrabarty, in this respect sees the 2008 Bombay massacre as having its roots in the politics of Partition, and she assures that historically, "the mutual relationship between the Hindus and the Muslims was without any sort of differential hindrance: there was a profound understanding as well as a strong feeling of brotherhood prevailing between the two communities" (147). The outbreaks of violence leading up to demolition of the Babri Masjid mosque (1992), or the 2002 Gujarat pogroms against the Muslim population are just a few examples of how the communalism born out of the violence of Partition continues to play a fundamental role in contemporary Indian life. Communalism, furthermore, is continuing to be instrumentalised for expedient ends and, as Fraser argues, the December 1992 Kolkata riots, which were daubed as a Muslim reaction to the 1992 destruction of the Babri Masjid mosque Ayodhya were, in fact, a ruse for land grabbing (Fraser 39). In a similar vein, Arundhati Roy in Listening To Grasshoppers: Field Notes On Democracy (2008) evidences how the rise of the Bharatiya Janata Party in India is directly linked to the strategic manipulation of religious sentiments for political ends. Rather than learning the lessons of Partition, the BJP's renewing of Hindu exceptionalism stirs up unnecessary and dangerous communal sentiment. Roy provides the specific example of the BJP politician, Varun Gandhi of the Nerhu dynasty, who, in the 2009 Indian election campaign, called for the forced sterilisation of all Muslims as a means to stir up communal animosity and "consolidate his vote bank" (Roy XXXII). Other forms of symbolic violence against Muslims can be seen in the resurgence of what Chakrabarti evidences as the Bengal Legislative Politics between 1912 and 1936 of restricting cow slaughtering in Bengal. This was 
a historical affront to Muslim sensibilities, yet we have seen a current resurgence of these restrictive practices in January 2017, when the Mumbai High Court upheld the cow slaughter ban in Maharashtra. Communal violence is also present in Bangladesh where aggressive Islamic policy with little regard for religious minorities is also being implemented (despite the fact that the Bangladeshi state was founded upon a secular-socialist principle under the auspicious of the Awami League). The result of this cultural intransigence based on an ideological interpretation of religious practice, has resulted in direct violence against Hindus in 1990 and 1992 "perpetrated in connivance with the state machinery" (Fraser 38). Pakistan, as an ideological entity, was formed upon the idea of the new nation as being a home to Islam, and the rise of Hinduvta ideology in contemporary India is a mirror image of this pernicious coupling of national belonging and faith. Constructing nationhood within this exclusive ideology inevitably leads to the incitement of hatred against the excluded other. In the case of Hindu extremism, it is a convenient subterfuge to mask India's social ills, such as a persisting caste violence, the appropriation of tribal lands by corporate conglomerates, the continuing impoverishment of a large segment of the population, and so forth. One of the great paradoxes of contemporary Indian society is that, whilst many Hindus no longer support the oppressive nature of the caste system and eschew all forms of communal violence, the dark and unfathomable violence of Partition continues to cast its shadow upon present events.

Reviews sent to author: 15 October 2017 Revised paper accepted for publication: 22 January 2018 


\section{REFERENCES}

Bandyopadhyay, Manik. “The Ledger” In Bashabi Fraser (ed.) Bengal Partition Stories: An Unclosed Chapter. Anthem, 2006.

Batabyal, Rakesh. Communalism in Bengal: From Famine to Noakhali, 1943-47. Sage, 2005.

Bhalla, Alok. Partition Dialogues: memories of a lost home. Oxford University Press, 2007.

Chakrabarty, Bidyut. The Partition of Bengal and Assam, 1932-1947. Routledge, 2004.

Chanraborty, Paulomi. The Refugee Woman: Partition of Bengal, Women, and the Everyday of the Nation. UMI: Dissertation Services. 2010.

Chatterji, Joya. Bengal Divided: Hindu Communalism and Partition 1932-1947. Cambridge University Press, 1994.

Dixit, Prabha. Communalism: A Struggle For Power. Longman Oriental 1974.

Fraser, Bashabi (ed). Bengal Partition Stories: An Unclosed Chapter. Anthem, 2006.

Gangopadhyay, Sunil. Arjun. Trans. Chitrita Banerji-Abdullah. Penguin, 1987.

Grosh, Nabendu. "Insignificance" In Bashabi Fraser (ed) Bengal Partition Stories: An Unclosed Chapter. Anthem Press, 2006.

Grosh, Nabendu. “The Saviour”, In Bashabi Fraser (ed.) Bengal Partition Stories: An Unclosed Chapter. Anthem, 2006.

Palit, Dibyendu. "Hindu". In Bashabi Fraser (ed.) Bengal Partition Stories: An Unclosed Chapter. Anthem, 2006.

Pandey, Gyanendra. Remembering Partition: Violence, Nationalism and History of India. Cambridge University Press, 2003.

Paushali, Chakrabarty. "Sixty Two Years Down Memory Lane: Retracing Identities in the Partition Narrative in Bengal." In Castillo, Debra and Kavita Panjabi. Cartographies of Affect: Across Borders in South Asia \& The Americas. Worldview Publications, 2011.

RaY, Renuka. My Reminiscences: Social development in the Gandhian Era and After. Bhatkal and Sen 2005 [1982].

Roy, Arundhati. Listening To Grasshoppers: Field Notes On Democracy. Penguin 2013 [2008].

Sarkar, Sumit. The Swadeshi Movement in Bengal. Permanent Black, 1973.

Sengupta, Achintya Kumar. "Treaty” In Bashabi Fraser (ed.) Bengal Partition Stories: An Unclosed Chapter. Anthem, 2006.

Sengupta, Debjani. The Partition of Bengal: Fragile Borders and New identities. Cambridge University Press, 2016.

Sikdar, Sunanda. A Life Long Ago. Trans. Anchita Ghatak. Penguin, 2012.

Siraj, Sayyed Mustafa. "India”. In Bashabi Fraser (ed.) Bengal Partition Stories: An Unclosed Chapter. Anthem, 2006. 